\title{
anemon
}

Muş Alparslan Üniversitesi Sosyal Bilimler Dergisi

Journal of Social Sciences of Muş Alparslan University

Yı/YYear: 2017 • Cilt/Volume: 5 • Sayı/Number: 2

ISSN: 2147-7655 • e-ISSN: 2149-4622

ÖZGÜN ARAŞTIRMA • ORIGINAL ARTICLE

\section{Din Kültürü ve Ahlak Bilgisi Öğretmen Adaylarının Değer Yönelimleri: İlahiyat - DKAB Karşılaştırması}

\author{
Mehmet Kamil COSKUN ${ }^{1, a}$ \\ ${ }^{1}$ Doç. Dr., Muş Alparslan Üniversitesi, İslami İlimler Fakültesi- Muş / Türkiye \\ Başvuru tarihi: 10 Ocak 2017 \\ Düzeltme tarihi: 14 Şubat 2017 \\ Kabul tarihi: 20 Şubat 2017
}

Öz

$\mathrm{Bu}$ araştırmanın amacı, din kültürü ve ahlak bilgisi öğretmen adaylarının değer yönelimlerinin tespiti ve farklı değişkenler açısından incelenmesidir. Örneklem olarak 2015-2016 öğretim yılında Atatürk Üniversitesi, Dicle Üniversitesi, İnönü Üniversitesi, Marmara Üniversitesi, Ondokuz Mayıs Üniversitesi, Uludağ Üniversitesi ve Selçuk Üniversitesinin ilahiyat ile din kültürü ve ahlak bilgisi (DKAB) eğitimi programlarında öğrenim gören 348'i erkek, 102'si kı olmak üzere toplam 450 öğretmen adayı seçilmiştir Veri toplama araçları olarak, Kuşdil ve Kağıtçıbaşı tarafindan geliştirilen Schwartz Değerler Listesi ve araştırmacı tarafından hazırlanan kişisel bilgi formu kullanılmıştır.

Araştırmanın sonucunda öğrencilerin cinsiyete göre değer eğilimlerinin; Başarı, Hazcılık, Uyarılım birey düzeyi değerlerinde kız öğrenciler lehine anlamlı şekilde farklılaştığı anlaşılmıştır. Öğrencilerin sınıf düzeyleri ve değer eğilimleri arasındaki ilişkiye bakıldığında; Evrenselcilik, Gelenek ve Güvenlik birey düzeyi değerlerinde elde edilen puanların, üçüncü sınıf öğrencileri lehine anlamlı şekilde farklılaştığı görülmüştür. Öğrencilerin öğrenim gördükleri lisans programının değer yönelimlerini anlamlı şekilde farklılaştırmadığı anlaşılmıştır.

\section{Anahtar Kelimeler}

Schwartz Değerler Ölçeği, Din Kültürü ve Ahlak Bilgisi, Değer Yönelimi

\footnotetext{
a Sorumlu Yazar/Correspoding Author: Muş Alparslan Üniversitesi, İslami İlimler Fakültesi, Din Kültürü ve Ahlak Bilgisi Eğitimi Bölümü, 49250, Muş / Türkiye.

e-posta: mk.coskun@alparslan.edu.tr 


\section{Value Orientations of Pre-service Teachers of Religion: Comparison of Divinity and Religious Education}

\section{Abstract}

The aim of this research is to examine the value orientations of pre-service teachers of religious culture and ethics in terms of different variables. The sampling of the research consists of 450 students studying in divinity and in the department of religious culture education at Ataturk University, Dicle University, Inonu University, Ondokuz Mayis University, Selcuk University and Uludag University between 2015 and 2016 education year. As data collection tools, the Schwartz Values List developed by Kuşdil and Kağıtçıbaşı (2000) and the personal information form prepared by the researcher were used.

As a result of the research, it was understood that students' value orientation to Success, Conformity, and Stimulation differed significantly in favor of female students. When the relationship between the class levels of the students and the value tendencies is examined; Universalism, Tradition and Security scores obtained at individual level values differed significantly in favor of third grade students. It has been understood that students' degree programs do not significantly differentiate scores at any individual level value.

\section{Keywords}

Schwartz Values Scale, Religious Culture and Moral Knowledge, Value Orientation

\section{GİRIŞ}

Son çeyrek yüzyıla bakıldığında değerlerin sosyal bilimler alanında araştırma konusu olarak ele alındığı görülecektir. Değerlerin insanların duygu, düşünce ve davranışlarını yakından ilgilendiriyor olması, bu ilgiyi etkileyen önemli bir faktördür. Sosyal bilimcilerin kanaatine göre değerler insan davranışlarını açıklamada vazgeçilmez bir öneme sahiptir (Kuşdil ve Kağıtçıbaşı, 2000'den aktaran: Dilmaç vd., 2008). Değerlerin hem bireysel tutum ve davranışları ve bilişsel süreçleri etkilediği; hem de toplumun kültürel kalıplarıyla etkileşimde bulunduğu ve onları yansıttığı, davranış bilimciler ve sosyal psikologlar tarafindan kabul edilmektedir.

Değer kavramı merkeze alarak psikoloji, sosyoloji ve antropoloji gibi alanlarda çalışan davranış bilimcileri tarafından ulaşılan sonuçlara göre değer kavramının tanımı üzerinde önemli ölçüde birleşildiği görülmektedir. Yapılan tanımların ortak noktaları temel alınacak olursa değerler bireyin kendisini ve çevresini algılama ve anlamlandırmada zemin oluşturan, tercihleri ve tutumlara tesir ederek davranışları yönlendiren referans noktaları olarak tanımlanabilir (Güngör, 1998; Yapıc1, 2009). Bu manada değerler; eylemlere veya inançlara değer biçen, karar vermede referans noktası olan, davranışlara kılavuzluk eden esaslara, temel inançlara, düşüncülere, standartlara veya hayat duruşuna 
göndermede bulunmak için kullanılır. Tüm bu inançlar, idealler, standartlar, hayat duruşu kişisel bütünlük veya kişisel kimlikle de yakından ilişkilidir (Halstead ve Taylor, 1996: 4). Değerler, insanların hayat felsefelerinin temel dinamiklerindendir. Kişinin dünya görüşü ve hayat felsefesi sahip olduğu değerler küresinde mahfuzdur. Değerler dünyası insanın hayatına yön verir, eylemlerini yönlendirir ve kişilik bütünlügünü oluşturur (Rokeach, 1973). İnanç nokta-i nazarından değer, dünyamızın belli bir kısmıyla ilgili idrak, duygu ve bilgilerimizin terkibi anlamında gelmektedir. Ancak değer, inancın çok hususi bir hali olması hasebiyle ondan daha üst düzeyde bir zihni manzumedir. Şöyle ki bir değer bir tek inanca değil, organize olmuş bir grup inanca tekabül eder. İnsanlara yardımcı olma değeri, bizim insan ilişkileriyle ilgili hayat tecrübelerimizden doğmuştur ve bu değerin kazanımında birden fazla inancın katkısı vardır (Güngör, 1998: 28).

Değerler hakkında pek çok teori vardır. Yoğun bir şekilde Rokeach (1973) ve Kluckhohn'den (1951) etkilenen Schwartz'ın teorisi, istenilen değerleri, değişim hedeflerini, önemdeki değişimi, insanların hayatındaki ilkelere rehberlik eden yardımları tanımlar. Değerlerin içerik boyutu, değerler arasında birbirlerinden farklılaşır ve içerik boyutu aynı zaman da güdülemek amacının çeşidini tayin eder (Sarıcı Bulut, 2012). Düşünceden kaynaklanan değerlerin içeriğindeki farklı tipolojileri ele alan Schwartz (1992) göre; 65'ten fazla kültürde geçerli, dairesel şsekilde sıralanan Güç, Başarı, Hazcılık, Uyarılım, Özyönelim, İyilikseverlik, Gelenek, Uyma, Evrensellik ve Güvenlik olmak üzere toplam 10 temel değer vardır. Güç sosyal statü ve saygınlık kazanma, insanların ve kaynakların üzerinde hakimiyet kurmayı; Başarı sosyal standartlara göre kişisel yeterlilik göstermeyi; Hazcılık zevk ve duyumsal doyum sağlamayı; Uyarılım heyecan, yenilik arayışını; Özyönelim tercih yaparken bağımsız olmayı; İyilikseverlik başkaları hakkında iyilik gözetmeyi; Gelenek gelenekten gelen unsurlara saygı ve bağlılığı, Uyma toplumun beklentilerine halel getirecek hareket ve eğilimleri kısıtlamayı; Evrensellik bütün insanların ve doğanın iyiliğini gözetmek için anlayışlı, hoşgörülü, himayeci olmayı; Güvenlik ise toplum, ilişkiler ve bireyin kendisinin güvenli, dengeli ve istikrarlı olmasını ifade eder. Birbiriyle uyum içinde olan değerler, dairenin üstünde birbirine yakın yerleştirilmiştir. Birbiriyle uyumsuz olan değerler ise merkezden uzak noktalarda bulunurlar (Yapıc1 vd., 2012: 130-131).

Yukarıda kısaca sıralanan ve izah edilen on temel değer, dairesel sıralamada 4 ana grupta toplanmaktadır. Güç ve başarı, 'Kendini Geliştirme'; uyarılım ve özyönetim, 'Yeniliğe Açıklık'; evrensellik ve iyilikseverlik, 'Kendini Aşma'; güvenlik, uyma ve gelenek ise 'Muhafazakârlık' kategorisini oluşturur. Hazcılık hem Kendini Geliştirme hem de Yeniliğe Açıklık kategorilerinin içindedir. Kendini Geliştirme, Kendini Aşma boyutuyla tezat halindedir; çünkü kendini geliştirme bireyin kendi hedeflerini izlemesi üzerine odaklanırken, Kendini Aşma toplumun tamamının faydasını gözetmekle alakalıdır. Bağımsız davranma, düşünme, hissetme ve yeni deneyimlere açık olmakla ilgili olan Yeniliğe Açıklık boyutu ise kendini denetleme, değişime dirençli olmakla ilgili olan Muhafazakârlık boyutuyla çelişmektedir (Roccas, 2005; Schwartz, 1992'den aktaran: Yapic1 vd., 2012: 131).

Değerler üzerine araştırma yapmanın başlıca amaçlarından biri, insanlarda var olan değer yönelimlerini belirlemek, bu yönelimlerin onların tutum, davranış, toplumsal deneyim ve rolleriyle ilgili etkileşimlerini ortaya çıkarmaktır (Mehmedoğlu, 2006). Geleceğin öğretmenleri olarak öğretmen adaylarının nasıl bir kültürlenme ve sosyalleşme içerisinde 
olduğunun, yani değerler sisteminin nasıl olduğunun bilinmesi önemlidir. Öğretmenlerin değerlerinin öğrenci davranışlarını etkilediği ile ilgili birçok araştırma bulgusu vardır (Brophy ve Good, 1986; Dickinson, 1990; Gözütok, 1995; Varış, 1973'den aktaran: Sarı, 2005). Bu yönüyle okul, çocuğa uygun değerler yoluyla olumlu kişiliğin kazandırıldığı beşeri bir laboratuvar, öğretmenler ise laboratuvarda uygulama yapan insan kaynakları olarak görülebilir. Öğretmenlerin değer sahibi olmaları, onların rol model olmaları açısından da elzemdir. Buna bağlı olarak okulda rol model olan öğretmenler tarafindan yürütülen değerler eğitimi yoluyla karakteri olumlu yönde gelişen çocuk, ahlaki yaşamın bilişsel, duygusal ve davranışsal boyutlarını kavrayarak, değerleri anlama ve hayata taşıma noktasında hassasiyet taşımaya başlayacaktır (Lickona, 1996; Milson ve Ekşi, 2003'den aktaran: Balay ve Kaya 2014: 8). Bu açıdan bakıldığında eğitimde değer kazandırma süreci büyük önem arz etmekte. Zira bu süreç, karakter eğitiminin önemli bir parçası olmanın yanında, duyuşsal alanı tamamlama görevini de ifa etmektedir. Sevgi, saygı, birlikte yaşama, müsamaha, sosyal öncelikleri benimseme, ahlak temelli yaşam, kişiliği geliştirme, müspet karakteri inşa etme gibi çok geniş bir alanı kapsayan hedefler değerler eğitiminin içinde değerlendirilebilir (Tokdemir, 2007'den aktaran: Balay ve Kaya 2014: 8).

Din ve değerlerin birbirleriyle yakından ilişkili olması hasebiyle din eğitiminin de değerlerin oluşumu, sürekliliği ve yeni nesillere aktarımı ile doğrudan ilişkili olduğu söylenebilir. Din ve eğitim alanlarında istihdam edilen ilahiyat ve DKAB programı öğrencilerinin bu görevleri gerçekleştirme başarısı onların değerleriyle yakından ilişkilidir. Bu araştırmanın amacı, din kültürü ve ahlak bilgisi öğretmen adaylarının değer yönelimlerinin cinsiyet, sınıf düzeyi ve öğretim programı değişkenlerine göre anlamlı şekilde farklılaşıp farklılaşmadığını saptamaktır. Yaygın din hizmetleri ve örgün din eğitimi alanında istihdam edilecek olan bu öğrencilerin değer yönelimlerini belirlemek, öğrencilerin bu alandaki mesleki yeterlikleri konusunda bakış açısı sağlayacağı gibi, din gibi hassas bir alanın eğitimini yapan yükseköğretim kurumundaki eğitimi anlamlandırmalarını anlamada da etkili olacaktır. Zira öğrenci, bir taraftan aldığı dini bilgiyi değerlerinin yönlendirmesi ile içselleştirirken, diğer taraftan bilgisinin davranışa dönüşmesiyle ulaştığı sonuçlar ve bu sonuçların beklentilerini karşılayıp karşılamadığı da değerlerini etkilemektedir (Arslan ve Tunç, 2013).

\section{YÖNTEM}

Araştırma, veri bağlamında nicel bir paradigmaya sahiptir. Çalışmada, ilişkisel tarama modeli kullanılmıştır. Örneklem olarak zaman, maddiyat ve çaba sarf etme etkenleri ile ilgili uygun amaçlı örneklem kullanılmıştır. Araştırmanın örneklemini belirlerken, tesadüfî küme örnekleme yöntemi seçilmiştir. Araştırmanın evreni, 2015-2016 öğretim yılında Atatürk, Dicle, İnönü, Marmara, On dokuz Mayıs, Uludağ ve Selçuk Üniversitelerinin ilahiyat ve DKAB programlarında öğrenim görmekte olan öğretmen adaylarından oluşmaktadır. Araştırmanın örneklemi ise söz konusu üniversitelerin ilahiyat ve DKAB programlarında öğrenim gören 348'i erkek, 102'si kız olmak üzere toplam 450 öğretmen adayından oluşmaktadır. Araştırmada likert tipi ölçek kullanılmıştır. Bu bağlamda araştırma verileri Schwartz (1992) tarafından geliştirilen Değerler Listesi ve araştırmacı tarafından oluşturulan kişisel bilgi formu kullanılarak toplanmıştır. 
Kuşdil ve Kağıtçıbaşı (2000) tarafindan yapılan çalışmada değer tipleri düzeyi için güvenilirlik katsayıları 0.51-0.77, değer grupları için 0.77-0.83 arasında değişmekte olup bu katsayılar Evrenselcilik için 0.77, Iyilikseverlik için 0.76, Hazcllık için 0.54, Güç için 0.75, Başarı için 0.66, Uyarılım için 0.70, Özyönelim için 0.69, Gelenek için 0.63, Uyma için 0.51, Güvenlik için 0.59 olarak bulunmuştur. Ayrıca ana değer grupları iç tutarlılık analiz sonuçlarına baktığımızda; Muhafazakarlık grubu için 0.80, Değişme değer grubu için 0.81, Özaşkınlık değer grubu için 0.81, Özgenişletim değer grubu için 0.84 olarak hesaplanmıştır (Dilmaç vd., 2008: 73). Öğrencilerin değer yönelim puanlarını çeşitli değişkenlere göre incelemek amacıyla aritmetik ortalama, $t$ testi ve tek yönlü ANOVA analiz teknikleri kullanılmıştır. Anlamlılık düzeyi olarak $\mathrm{p}<.05$ seçilmiştir.

\section{BULGULAR}

Gü̧̧ kategorisinde ilahiyat öğrencilerinin ortalaması (X: 17.96) iken, DKAB öğrencilerinin $(X:$ 17.19)'dur. Aralarında anlamlı fark bulunamamıştır $(p=.153)$. Bu kategoride kız öğrencilerin ortalaması $(X: 17.88)$ iken, erkek öğrencilerin ortalaması (X: 17.48 )'dir. Aralarında anlamlı fark görülmemiştir $(p=.538)$. Yine aynı kategoride üçüncü sınıf öğrencilerinin ortalaması (X: 17.84) iken, dördüncü sınıf öğrencilerinin ortalaması (X: 16.93)'dür. Aralarında anlamlı fark görülmemiştir $(p=.127)$.

Başarı kategorisinde ilahiyat öğrencilerinin ortalaması $(X: 19.20)$ iken, DKAB öğrencilerinin $(X:$ 19.05)'dir. Aralarında anlamlı fark bulunamamıştır $(p=.784)$. Bu kategoride kız öğrencilerin ortalaması $(X: 20.53)$ iken, erkek öğrencilerin ortalaması ( $X$ : 18.72)'dir. Aralarında kızlar lehine anlamlı fark görülmüştür $(p=.004)$. Buna göre kız öğrenciler Başarı değerine erkek öğrencilerden daha güçlü olarak yönelmektedir. Yine aynı kategoride üçüncü sınıf öğrencilerinin ortalaması $(X: 19.25)$ iken, dördüncü sınıf öğrencilerinin ortalaması (X: 18.82)'dir. Aralarında anlamlı fark görülmemiştir ( $p=.457)$.

Hazcllık kategorisinde ilahiyat öğrencilerinin ortalaması (X: 12.52) iken, DKAB öğrencilerinin $(X:$ 12.56)'dır. Aralarında anlamlı fark bulunamamıştır $(p=.931) . \mathrm{Bu}$ kategoride kız öğrencilerin ortalaması $(X: 14.12)$ iken, erkek öğrencilerin ortalaması $(X$ : $12.08)$ 'dir. Aralarında kızlar lehine anlamlı fark görülmüsstür $(p=.000)$. Buna göre kız öğrenciler Hazcllık değerine erkek öğrencilerden daha güçlü olarak yönelmektedir. Yine aynı kategoride üçüncü sınıf öğrencilerinin ortalaması $(X: 12.60)$ iken, dördüncü sınıf öğrencilerinin ortalaması $(X: 12.39)$ 'dur. Aralarında anlamlı bir fark görülmemiştir $(p=.667)$.

Uyarllım kategorisinde ilahiyat öğrencilerinin ortalaması (X: 10.36) iken, DKAB öğrencilerinin $(X: 10.15)$ 'dir. Aralarında anlamlı fark bulunamamıştır $(p=.577)$. Bu kategoride kız öğrencilerin ortalaması $(X: 11.21)$ iken, erkek öğrencilerin ortalaması ( $X$ : 9.97)'dir. Aralarında kızlar lehine anlamlı fark görülmüsşür $(p=.006)$. Buna göre kız öğrenciler Uyarıllm değerine erkek öğrencilerden daha güçlü olarak yönelmektedir. Üçüncü ve dördüncü sınıf öğrencilerinin Uyarılım kategorisindeki ortalaması eşittir ( $X$ : 10.25).

Özyönelim kategorisinde ilahiyat öğrencilerinin ortalaması $(X: 25.04)$ iken, DKAB öğrencilerinin $(X: 25.35)$ 'dır. Aralarında anlamlı fark bulunamamıştır $(p=.931) . \mathrm{Bu}$ kategoride kız öğrencilerin ortalaması $(X: 25.62)$ iken, erkek öğrencilerin ortalaması $(X$ : 
25.07)'dir. Aralarında anlamlı fark görülmemiştir ( $p=.376)$. Yine aynı kategoride üçüncü sınıf öğrencilerinin ortalaması $(X: 25.43)$ iken, dördüncü sınıf öğrencilerinin ortalaması (X: 24.61)'dir. Aralarında anlamlı fark görülmemiştir $(p=.149)$.

Evrenselcilik kategorisinde ilahiyat öğrencilerinin ortalaması $(X: 37.68)$ iken, DKAB öğrencilerinin $(X: 38.92)$ 'dir. Her ne kadar aralarında DKAB programı lehine fark görülse de bu fark anlamlı düzeyde değildir $(p=.066)$. Bu kategoride kı öğrencilerin ortalaması $(X: 38.47)$ iken, erkek öğrencilerin ortalaması (X: 38.25)'dir. Aralarında anlamlı fark görülmemiştir $(p=.785)$. Yine aynı kategoride üçüncü sınıf öğrencilerinin ortalaması $(X$ : 38.74) iken, dördüncü sınıf öğrencilerinin ortalaması (X: 37.25)'dir. Aralarında üçüncü sınıf lehine anlamlı fark görülmüştür $(p=.045)$. Buna göre üçüncü sınıf öğrencileri, Evrenselcilik değerine dördüncü sınıf öğrencilerine göre daha güçlü olarak yönelmektedir.

İyilikseverlik kategorisinde ilahiyat öğrencilerinin ortalaması (X: 39.33) iken, DKAB ögrencilerinin $(X: 40.31)$ 'dir. Her ne kadar aralarında DKAB programı lehine farklı görülse de bu farklılaşma anlamlı düzeyde değildir $(p=.094)$. Bu kategoride k1z öğrencilerin ortalaması $(X: 39.32)$ iken, erkek öğrencilerin ortalaması (X: 39.97)'dir. Aralarında anlamlı farklılaşma görülmemiştir $(p=.356)$. Yine aynı kategoride üçüncü sınıf öğrencilerinin ortalaması $(X: 39.99)$ iken, dördüncü sınıf öğrencilerinin ortalaması $(X: 39.41)$ 'dir. Aralarında anlamlı farklılaşma görülmemiştir $(p=.364)$.

Gelenek kategorisinde ilahiyat öğrencilerinin ortalaması $(X: 20.25)$ iken, DKAB öğrencilerinin ( $X: 20.43)$ 'dür. Aralarında anlamlı farklılaşma görülmemiştir ( $p=.694)$. Bu kategoride kız öğrencilerin ortalaması $(X: 20.50)$ iken, erkek öğrencilerin ortalaması $(X:$ 20.29)'dur. Aralarında anlamlı farklılaşma görülmemiştir $(p=.695)$. Yine aynı kategoride üçüncü sınıf öğrencilerinin ortalaması $(X:$ 20.66) iken, dördüncü sınıf öğrencilerinin ortalaması ( $X: 19.57)$ 'dir. Aralarındaki farklılaşma anlamlı düzeydedir $(p=.023)$. Buna göre üçüncü sınıf öğrencileri Gelenek değerine, dördüncü sınıf öğrencilerine göre daha güçlü olarak yönelmektedir.

Uyma kategorisinde ilahiyat öğrencilerinin ortalaması $(X: 17.37)$ iken, DKAB öğrencilerinin (X: 17.40)' dır. Aralarında anlamlı farklılaşma görülmemiştir $(p=.935)$. Bu kategoride kız öğrencilerin ortalaması $(X: 16.97)$ iken, erkek öğrencilerin ortalaması $(X$ : $17.51)$ 'dir. Aralarında anlamlı farklılaşma görülmemiştir $(p=.164)$. Yine aynı kategoride üçüncü sınıf öğrencilerinin ortalaması $(X: 17.57)$ iken, dördüncü sınıf öğrencilerinin ortalaması ( $X: 16.95)$ 'dir. Aralarındaki farklılaşma anlamlı düzeyde değildir $(p=.085)$.

Güvenlik kategorisinde ilahiyat öğrencilerinin ortalaması ( $X: 35.15)$ iken, DKAB öğrencilerinin ( $X: 34.55)$ 'dir. Aralarında anlamlı farklılaşma görülmemiştir $(p=.246)$. Bu kategoride kız öğrencilerin ortalaması $(X: 33.94)$ iken, erkek öğrencilerin ortalaması $(X$ : 35.11)'dir. Aralarındaki farklılaşma anlamlı düzeydedir $(p=.048)$. Buna göre erkek öğrenciler Güvenlik değerine, kız öğrencilere göre daha güçlü olarak yönelmektedir. Yine aynı kategoride üçüncü sınıf öğrencilerinin ortalaması $(X: 35.30)$ iken, dördüncü sınıf öğrencilerinin ortalaması $(X: 33.75)$ 'dir. Aralarındaki farklılaşma anlamlı düzeydedir $(p=.006)$. Buna göre üçüncü sınıf öğrencileri Güvenlik değerine, dördüncü sınıf öğrencilerine göre daha güçlü olarak yönelmektedir. 


\section{TARTISSMA}

Cinsiyet faktörünün değer yönelimleri üzerindeki etkisini ortaya çıkaran ilgili analizlere bakıldığında Başarı, Hazcılık ve Uyarılım değerleri açısından cinsiyetler arası anlamlı düzeyde bir farklılaşma olduğu görülmektedir. Her üç değere yönelimdeki farklılaşmanın bayan öğretmen adayları lehine olduğu anlaşılmıştır. Diğer değer tiplerine yönelimde anlamlı farklılaşma görülmemiştir. Dilmaç vd., (2008) tarafindan yürütülen araştırmada Evrensellik, Özyönelim ve Güç değerleri açısından cinsiyetler arası farklılık olduğu; Evrensellik ve Özyönelim boyutunda farklılaşma erkek öğretmen adayları lehineyken, Güç boyutunda k1z öğrencilerin lehine olduğu gözlenmiştir. Mehmedoğlu (2006) tarafından yürütülen araştırmada ise kızların Hazcılık, Özyönelim, Evrenselcilik, İyilikseverlik ve Gelenek değerlerine, erkek öğrencilerin ise Güç, Başarı, Uyarılım ve Uyma değerlerine daha fazla önem verdiğine işaret edilmiştir. Karaca (2008) tarafindan yürütülen araştırmaya göre, Hazcılık erkek öğrencilerin k1z öğrencilere oranla; Özyönelim, Evrenselcilik ve Güvenlik ise kız öğrencilerin erkek öğrencilere oranla daha fazla önem verdikleri değerlerdir. Arslan ve Tunç (2013) tarafından yürütülen araştırmada ulaşılan bulgulara göre, öğrenciler arasında cinsiyete göre değer yönelimi farklılaşmasının erkekler lehine (heyecan ve yenilik arayışı temalarının olduğu) Uyarılım değer tipinde; kızlar lehine ise Evrenselcilik, Iyilikseverlik, Uyma değer tiplerinde bir farklılaşma gözlenmektedir. Buna göre en fazla değer farklılaşması kızlarda görülmektedir. Kızlar, erkeklere oranla Evrenselcilik, Iyilikseverlik ve Uyma değer tiplerine daha fazla yönelim göstermektedirler. Sarıcı Bulut (2012) tarafından yürütülen araştırmada öğrencilerin cinsiyetlerine göre değer eğilimlerinin, Iyilikseverlik, Uyarılım, Uyma ve Güvenlik alt ölçeklerinde farklılaştığı, erkek öğrencilerin Uyarılım eğilimlerinin k1z öğrencilerin Uyarılım eğilimlerinden daha yüksek olduğu, k1z öğrencilerin İyilikseverlik, Uyma ve Güvenlik eğilimlerinin erkek öğrencilerden daha yüksek olduğu bulunmuştur.

Sınıf düzeyi faktörünün değer yönelimleri üzerindeki etkisini ortaya çıkaran ilgili analizlere bakıldığında Evrenselcilik, Gelenek ve Güvenlik değerleri açısından sınıf düzeyleri arası anlamlı farklılaşma olduğu, bu farklılaşmanın her üç değerde de üçüncü sınıf öğrencileri lehine olduğu anlaşılmıştır. Selçuk Üniversitesi öğrencileri üzerinde yapılan araştırmada Uyma değerinde en yüksek aritmetik ortalamayla birinci sınıflar; Güç, Gelenek, Iyilikseverlik, Uyarllım ve Evrenselcilik değerlerinde ikinci sınıflar; Özyönelim ve Güvenlik değerlerinde dördüncü sınıflar, Hazcılık ve Başarı değerlerinde üçüncü sınıflar aritmetik ortalamaları bakımından diğer sınıflara oranla yüksek puana sahiptirler. Söz konusu araştırmada farklı sınıf düzeylerindeki öğretmen adaylarının değer algıları ortalamaları arasındaki farklılığı ortaya koymak amacıyla hesaplanan F değerlerinden sadece Gelenek değer algısı alt boyutunda anlamlı düzeyde farklılaşma olduğu anlaşılmıştır. Farklılaşmanın hangi grup lehine olduğunu tespit etmek amaciyla yapılan Tukey testi sonuçları incelendiğinde üçüncü sınıf öğrencilerinin Gelenek değer algılarının diğer sınıf düzeylerinden anlamlı düzeyde yüksek olduğu görülmüştür. $\mathrm{Bu}$ sonuca göre üçüncü sınıf öğrencilerin Gelenek değer algıları birinci sınıf, ikinci sınıf ve dördüncü sınıf öğrencilerinin Gelenek değer algılarına göre daha yüksek olduğu anlaşılmaktadır. (Dilmaç vd., 2008). Başka bir araştırmaya göre üçüncü sınıftaki öğretmen adaylarının birinci sınıftakilere kıyasla Özdenetim, Evrensellik ve Yardımseverlik alanlarında daha yüksek puanlar aldıkları; ikinci sınıftaki ögrencilerin ise 
birinci sınıftaki öğrencilere kıyasla Güvenlik alanında daha yüksek puan aldıkları gözlenmiştir (Dilmaç vd., 2009). Yapıcı vd., (2012) tarafından yürütülen araştırmada, DKAB birinci ve dördüncü sınıf öğrencileri arasında Özyönelim, İyilikseverlik ve Uyma değerlerinde dördüncü sınıf lehine gözlenen artış istatistiksel olarak anlamlı bulunmuştur. Başarı, Uyarılım, Evrensellik, Güç, Hazcllık, Gelenek, Güvenlik ve Dindarlık değerlerinde ise anlamlı bir farklılaşma görülmemiştir. Karaca'nın (2008) araştırmasına bakıldığında, birinci sınıf öğrencilerinin Evrenselcilik ve Uyma değerlerini, üçüncü sınıf öğrencilerinin Güç, Başarı, Uyarılım, Özyönelim, Lyilikseverlik, Gelenek ve Güvenlik değerlerini, dördüncü sınıf öğrencilerinin ise Hazcllık değer tipini diğer sınıflara oranla daha fazla önemsedikleri anlaşılmaktadır. İlk sınıflarda bulunan öğrencilerin değerlere verdikleri önem düzeyleri, Hazcıllk değer tipi hariç, son sinıflarda bulunan öğrencilerden daha yüksektir. İkinci sınıf öğrencilerinde bütün değerlere verilen önem düzeylerinde bir azalma görülmektedir. Arslan ve Tunç (2013) tarafından yürütülen araştırmada, öğrenciler arasında sınıflarına göre istatistiksel anlamda değer yönelimi farklılaşmasının tümünün üçüncü ve dördüncü sinıflar lehine olduğu görülmüştür. Bunlar Güç, Başarl, Özyönelim, Evrenselcilik, Gelenek, Uyma değer tipleridir. Buna göre öğrencilerin ilahiyat fakültesinde aldıkları eğitimleri onların yukarıda verilen değer tiplerinde olumlu bir yönelime neden olmaktadır. Sarıcı Bulut (2012) tarafından yürütülen araştırmada, Güç, Hazcılık ve Uyarılım alt ölçeklerinden elde edilen puanların farklılaştığı, ikinci sınıf ve dördüncü sınıf öğrencilerin Güç eğilimlerinin üçüncü sınıf öğrencilerin Gü̧̧ eğilimlerinden daha yüksek olduğu, dördüncü sınıf öğrencilerinin Hazcllık eğilimlerinin ikinci sınıf öğrencilerin Hazcıllk eğilimlerinden daha yüksek olduğu, 1., 2. ve 4. sınıf öğrencilerinin Uyarılım eğilimlerinin üçüncü sınıf öğrencilerin Uyarılım eğilimlerinden daha yüksek olduğu bulunmuştur. Bu bulgular Dilmaç vd., (2008)'nin ikinci sınıf öğrencilerinin $G \ddot{u} c ̧$ eğilimlerinin daha yüksek olduğu bulgusuyla örtüşmekte, Dilmaç vd., (2009)'nin çalışmalarıyla örtüşmemektedir (Sarıcı Bulut, 2012: 233).

Öğrencilerin öğrenim gördükleri bölüme göre değer yönelimlerinde farlıllk olup olmadığını ortaya çıkaran ilgili analizlere bakıldığında, program türünün tüm değerlerde anlamlı düzeyde bir farklılaşmaya sebep olmadığı görülmüştür. Buna göre İlahiyat ve DKAB öğretmenliği programlarında eğitim gören öğrencilerin değer yönelimleri arasında istatistiksel olarak bir farklılık yoktur. Karaca (2008) tarafindan yapılan araştırmada, farklı bölüm öğrencilerinin birey düzeyi değer yönelimleri ortalamalarının birbirine yakın olduğu; ancak ilahiyat öğrencilerinin Uyma değer tipine, DKAB öğrencilerinin ise Güç, Başarı, Hazcllık, Uyarıllum, Özyönelim, Evrenselcilik, İyilikseverlik, Gelenek ve Güvenlik değer tiplerine daha fazla önem verdikleri anlaşılmıştır. Aynı şekilde Yapıcı ve Zengin (2003), ilahiyat ve DKAB bölümlerinde öğrenim gören öğrencilerin değer tercih sıralamalarında istatiksel açıdan anlamlı bir farklılı̆̆ın oluşmadığını saptamakla beraber iki bölüm arasında değer sıralamaları bakımından küçük farklar gözlenmiştir. İlahiyat bölümü öğrencilerinin ilk tercihlerini dinî değerler, ikinci tercihlerini sosyal değerler oluştururken, DKAB bölümü öğrencileri sosyal değerleri ilk sıraya, dinî değerleri ikinci sıraya yerleştirmişlerdir. Araştırmada, her iki bölümün dinî değerleri ön planda tutmalarını gerek din eğitiminin etkisiyle gerekse aynı sosyal çevrede karşılıklı etkileşim içerisinde bulunmaları şeklinde açıklanmıştır (Karaca, 2008: 89). Arslan ve Tunç (2013: 23) tarafından yürütülen araştırmadaki bulgular da öğrenciler arasında öğretim programlarına göre bir değer yönelimi farklılaşmasının olmadığını, ortalamalarda bir farklılık görülse de $\mathrm{T}$ testinin bu farklılığı anlamlı olarak doğrulamadığını göstermiştir. 
İlahiyat fakültelerinde uygulanan programlar öğrencilerin değer yönelimleri arasında anlamlı bir farklılığa yol açmaması ilahiyat fakültesi öğrenci kaynağının benzer ortamlardan gelmesi ve bugünkü şartlar itibariyle aynı ortamda eğitim görmeleri ile ilişkili olabilir (Arslan ve Tunç, 2013). Zira, DKAB dahil 5 farklı program öğrencileri üzerinde yapılan araştırmada, Evrenselcilik, Iyilikseverlik, Gelenek, Uyma ve Güvenlik birey düzeyi değerlerinde en yüksek puanı DKAB programı öğrencilerinin aldıkları ve bu kategorilerde aldıkları ortalama puanlarının, diğer programların (felsefe, İngilizce, fen ve teknoloji, resim-iş) öğrencilerinden anlamlı şekilde farklılaştığı; buna karşın Hazclllk birey düzeyi değerinde en düşük ortalama puanı aldıkları gözlenmiştir (Yapıcı vd., 2012). Aynı şekilde Balay ve Kaya (2014) tarafından yapılan araştırma, öğretmen adaylarının ahlaki değer yönelimlerinin Saygl, Adalet, Sadakat, Cesaret, Dürüstlük, Zarafet ve Güven boyutlarında öğrenim gördükleri programa göre anlamlı farklılık gösterdiğini ortaya koymuştur. Örneğin DKAB programında okuyanların, resim-iş ve müzik programlarında okuyanlara; resim-iş programında okuyanların ise, müzik programında okuyanlara göre daha yüksek düzeyde Saygı ve Sadakat algısına sahip oldukları görülmüştür. Diğer yandan aynı araştırmada DKAB programında okuyan öğretmen adaylarının, sınıf, resimiş ve müzik öğretmenliği programlarında okuyanlara kıyasla daha yüksek Adalet algısına sahip oldukları görülmektedir (Balay ve Kaya, 2014).

\section{SONUÇ}

Bu çalışma, din kültürü ve ahlak bilgisi öğretmen adaylarının değer yönelimlerinin cinsiyet, sınıf düzeyi ve program türü değişkenlerine bağlı olarak ne düzeyde farklılaştığını belirlemeye yönelik yapılan çalışmalardan biri olup sonuçları itibarıyla Türkiye'de yapılan önceki araştırmalara benzer özellikler taşımaktadır. Araştırma sonucunda Başarı, Hazcılık ve Uyarılım değerleri acısından cinsiyetler arası anlamlı farklılaşma bulunmuştur. Kız öğrencilerin bu değerlere erkek öğrencilerden daha güçlü olarak yönelmeleri, toplum tarafından kadınlardan beklenen değer yönelimlerine ters düştüğü söylenebilir; ancak toplumda vuku bulan sosyokültürel gelişmelerden dolayı kadınların bakış açlarında ve rollerinde değişiklikler olabilmektedir. Sınıf düzeyine bakıldığında, Evrenselcilik, Gelenek ve Güvenlik değerleri açısından üçüncü sınıf öğrencileri lehine anlamlı farklılık bulunmuştur.

Çalışmada program türüne (İlahiyat / DKAB) göre öğrencilerin değer yönelimlerinde bir farklılaşmanın olup olmadığına da bakılmıştır. Ortalamalarda farklılık görülmekle birlikte ilahiyat programı ile DKAB programı öğrencilerinin değer yönelimleri arasında istatistiksel olarak anlamlı bir farklılık görülmemiştir. Aslında DKAB lisans programına bakıldığında; değerler eğitimi, eğitim bilimleri ve felsefe grubu derslerinin ilahiyat lisans programlarına göre daha fazla olması nedeniyle, değer yönelimlerinde bir farklılaşma olacağı beklentisi uyanmaktadır. Ancak gerek bu araştırma gerek daha önce yürütülen araştırmalar (Yapıcı ve Zengin, 2003; Karaca, 2008; Yapıcı vd., 2012; Arslan ve Tunç, 2013), İlahiyat - DKAB temelli program türü değişkenine bağlı olarak değer yönelimlerinde oluşan farklılıkların istatistiksel olarak anlamlı düzeyde olmadığını göstermiştir. Buna karşın, farklı alan öğretmen adayları üzerinde yapılan araştırmalarda, ilahiyat - DKAB programı öğrencilerinin değer yönelimlerinin diğer alanların öğretmen adaylarının değer yönelimlerinden anlamlı şekilde farklılaştığı görülmüştür. 


\section{KAYNAKÇA}

Arslan, M., \& Tunç, E. (2013). İlahiyat Fakültesi Öğrencilerinin Değer Yönelimlerindeki Farklılaşmalar. Değerler Ĕ̈itimi Dergisi, 11(26), 7-39.

Balay, R., \& Kaya, A. (2014). Eğitim Fakültesinde Okuyan Öğretmen Adaylarının Ahlaki Değer Yönelimleri. Değerler Ĕ̆itimi Dergisi, 12(28), 7-45.

Dilmaç, B., Bozgeyikli, H., \& Çıkılı, Y. (2008). Öğretmen Adaylarının Değer Algılarının Farklı Değişkenler Açısından İncelenmesi. Değerler Eğitimi Dergisi, 6(16), 69-91.

Dilmaç, B., Deniz, M., \& Deniz, M.E. (2009). Üniversite Öğrencilerinin Öz-Anlayışları ile Değer Tercihlerinin İncelenmesi. Değerler Eğitimi Dergisi, 18, 9-24.

Güngör, E. (1998). Değerler Psikolojisi Üzerine Araştırmalar. İstanbul: Ötüken Yayınlar1.

Halstead, J. M., \& Taylor, M. J. (1996). Values in Education and Education in Values. London: The Falmer Press.

Karaca, R. (2008). İlahiyat Fakültesi Öğrencilerinin Değer Yönelimleri. Doktora Tezi, İstanbul: Marmara Üniversitesi

Kluckhohn, C. K. (1951). Values and Value Orientations in the Theory of Action. In T. Parsons and E. A. Shils (Eds.), Toward a general theory of action. Cambridge, MA: Harvard University Press.

Kuşdil, E. M., \& Kağıtçıbaşı, Ç. (2000). Türk Öğretmenlerin Değer Yönelimleri ve Schwartz Değer Kuramı. Türk Psikoloji Dergisi, 45, 59-76.

Mehmedoğlu, A. U. (2006). Gençlik, Değerler ve Din: Küreselleşme, Ahlak ve Değerler. İstanbul: Litera.

Rokeach, M. (1973). The Nature of Human Values. New York: The Free Press.

Sarı, E. (2005). Öğretmen Adaylarının Değer Tercihleri: Giresun Eğitim Fakültesi Örneği. Değerler Ĕ̆itimi Dergisi, 3(10), 73-88.

Sarıcı Bulut, S. (2012). Gazi Eğitim Fakültesi Öğrencilerinin Değer Yönelimleri. Uluslararası Türkçe Edebiyat Kültür Eğitim Dergisi 1(3), 216-238.

Schwartz, S. (1992). Universals in the content and structure of values: Theoretical advances and empirical tests in 20 countries. In M. P. Zanna, (Ed.), Advances in Experimental Social Psychology (pp.1-65). San Diego: Academic Press.

Yapıc1, A. (2009). Küreselleşme ve Değerler Krizi. Değerler Ĕ̆itimi Merkezi Dergisi, 7, 14-18.

Yapıc1, A., \& Zengin, Z.S. (2003). İlahiyat Fakültesi Öğrencilerinin Değer Tercih Sıralamaları Üzerinde Psikolojik Bir Araştırma: Çukurova Üniversitesi İlahiyat Fakültesi Örneği. Değerler Eğitimi Dergisi, 1(4), 173-206.

Yapıc1, A., Kutlu, M.O., \& Bilican, F.I. (2012). Öğretmen Adaylarının Değer Yönelimleri. Elektronik Sosyal Bilimler Dergisi, 11(42), 129-151. 